\title{
Activities of the Theosophical Society and the Order of the Star in the East in the Czech Lands until 1939
}

\author{
Józef Szymeczek (iD) https://orcid.org/0000-0002-6157-6324 \\ Centre for Studies of European Identity, Department of Civic Education \\ University of Ostrava \\ e-mail: jozef.szymeczek@osu.cz
}

\begin{abstract}
The study shows the penetration of the Theosophical movement into Austro-Hungarian territory, highlighting this process in the Czech lands from the end of the 19th century. It also examines the development of the Theosophical movement in the territory of Czechoslovakia during the interwar period, and analyses the conflict that occurred in the Theosophical circles as the result of accepting or rejecting the teachings of Jiddu Krishnamurti, recognised as the manifestation of Majtreja, but also as the expected Messiah. The analysis also considers the activities of the Star Order in the East, which was founded for the purpose of spreading the teachings of Krishnamurti.
\end{abstract}

Keywords: Theosophical Society, Order of the Star in the East, Western esotericism, Krishnamurti's mission, occultism, Adyar, Theosophical lodges in the Czech lands

Słowa kluczowe: towarzystwo teozoficzne, zakon gwiazdy, ezoteryzm zachodni, misja Krishnamurtiego, okultyzm, Adyar, loże teozoficzne na ziemiach czeskich

In the second half of the 19th century, under the pressure of research results of newly developing scientific fields such as psychology and neurology, a reflex of assertiveness of Western spiritualism occurred in a form of convergence of various trends in the Western esoteric and occult tradition, whose followers began to associate in new types of societies producing an alternative to the positivist, scientific understanding of the world. Such societies included numerous hermetic societies and associations, but also the Theosophical Society. An intellectual basis for Western esotericism was the belief in the existence of ancient wisdom that existed during the golden age, the remains of which have been held to contemporary times in oriental and occult sciences. ${ }^{1}$

${ }^{1}$ I.T. Budil, Spiritualismus a odvrácená strana př́rody, Praha 2017, p. 280. 


\section{Formation and development of the Theosophical Society}

The leading figure in the occultism of modern times is Helena Petrovna Blavatsky (1831-1891) who combined occultism, spiritualism, orientalism and conspiratorial sciences in her work, thus creating a suggestive scientific system which in the period before World War I gained great publicity in the Western world, both in intellectual circles as well as among ordinary people. Blavatsky's teachings are the basis for the Theosophical Society, which she founded together with Henry Steel Olcott (1832-1907) on 17 September 1875 in New York. ${ }^{2}$ Blavatsky was a Russian, while Olcott was an American. Blavatsky was born on 12 July 1831 in Jekaterinoslav (now Dnipropetrovsk) in Ukraine into the family of the tsarist army captain Peter von Hahn. ${ }^{3}$ She had a very bizarre life, which passed into many legends. From her youth she engaged in occultism, as she gained her first information on the occultism in the library of her great-grandfather, Prince Pavel Dolgorukov. She was very stubborn and nonconformist. She defied her family and married an old general, Nikofor Blavatsky, only to leave him and lead an independent life. She did not, however, resign from the financial support from her family, especially from her father. In London in 1851, after an accidental meeting with an unknown Indian man, she felt a desire to fulfil a unique mission to form a theosophical society. Before she did so, she had taken part in some preparations for the mission. Her whole life was a rich but chaotic and adventurous journey around various places in the world - from India, through the whole of Europe and Egypt to America. She claimed to have fought against the pope in the army of Garibaldi in the Battle of Mentana in 1867. ${ }^{4}$ The following year, according to her own words, she went to Tibet, where she became familiar with esoteric teachings of the "hidden masters," the mahatmas. Soon after founding the Theosophical Society she moved to India in 1878, and the seat of the Theosophical Society was transferred there as well (initially to Varanasi and then to Adyar near Madras in 1882). In 1879 she began publishing The Theosophist, a magazine which reached various places around the world. The Theosophical Society became an international phenomenon. Circles associated with the Theosophical Society were formed in the UK, France, and Ceylon, then also in other places around the world.

The theories she proclaimed contained Gnostic, Neoplatonic and various secret teachings given to her, as she claimed, by mahatmas in India and Tibet. She was the author of many publications, the most essential ones including Isis Unveiled (1877), The Secret Doctrine (vol. 1-3, 1888), and The Voice of the Silence (1889). In order to find the main thought of her very extensive and incoherent work, one could form a thesis (based on Smoley) that her work was an attempt to deprive the

2 J. Goodwin, Blavatsky and the First Generation of Theosophy, [in:] Handbook of the Theosophical Current, O. Hammer, M. Rothstein (eds.), Leiden-Boston 2013, pp. 17-20.

3 J.A. Santucci, Helena Petrovna Blavatsky, [in:] Dictionary of Gnosis \& Western Esotericism, W.J. Hanegraaff et al. (eds.), Leiden - Boston 2006, pp. 171-185. Also in: Carlson M., No Religion Higher than Truth. A History of the Theosophical Movement in Russia, 1875-1922, Princeton 1993.

${ }^{4}$ R. Smoley, Zakázaná víra. Gnostický odkaz od evangelii po da Vinciho kód, trans. A. Zábojníková, Praha 2009, p. 156. 
Jewish-Christian tradition of an unjustified (according to Blavatsky) claim to a monopoly on spiritual truth. ${ }^{5}$ Blavatsky refers to Gnostic traditions by claiming that "the secret doctrine," a basic esoteric teaching (experience) which is the basis for all religions, is a universal phenomenon. She considered that to claim that someone believes in the one true God, or has the only true God, was a manifestation of sectarian arrogance ${ }^{6}$ According to Theosophists, the purpose of their society was to create fraternity between nations, to develop mental powers hidden within every person, to study the internal element of all religions, and to study ancient Eastern literature. The very term "theosophy" comes from the Greek language (theos - God, sofia - wisdom) and means that a man becomes closer and closer to the wisdom of God which he should know and be guided by. The Theosophical Society proclaimed the slogan "There is no religion superior to the truth." Intellectuals of the main scientific trend ridiculed Blavatsky, claiming that she was creating mystical folly and unsophisticated gimmicks. After the disgrace she was exposed to in 1883 by Richard Hodgson, a worker of the Association for Mental Research in London, who claimed that all the evidence for her supernatural powers was fraudulent, she left India, probably in 1884, and lived temporarily in Italy, Germany and Belgium. Then she finally settled down in London, where she died on 8 May 1891. ${ }^{7}$

Her keen supporters in Central Europe included a German manufacturer named Gebhart from the Rhine city of Elberfeld who tried to convince Blavatsky to live in that city and make it the European Centre of the Theosophical Society. ${ }^{8}$ That did not happen, as she conferred that status on London, but in Elberfeld the first lodge of the Theosophical Society in Germany was formed in July, $1884 .{ }^{9}$ It was headed by Wilhelm Hübe-Schleiden, a colony official in Hamburg. After the upheavals experienced by the first generation of German theosophists due to accusations of charlatanism made towards Blavatsky, Franz von Hartmann became the leading figure of the German Theosophical movement (1838-1912). He was a doctor born in Bavaria who worked in America. In 1883, after reading Blavatsky's texts, he followed her through California and Japan to India. After two years he came back to Europe and in 1892-1900 he published the magazine Lotusblüthen, which became an important means of promoting theosophical ideas in Central Europe. In August 1896, the German Theosophical Society was founded (de. Deutsche Theosophische Gesellschaft). The two main centres of German Theosophy were the cities of Leipzig and Berlin, where another great theosophical activist, Rudolf Steiner (1861-1925) was active. Both the centres and their leaders (Hartmann in Leipzig and Steiner in Berlin) competed with each other, presenting different concepts about the future development of the Theosophical movement in Europe. Both thinkers also had different visions

${ }^{5}$ R. Smoley, op. cit., p. 158.

${ }^{6}$ Ibidem.

7 J.A. Santucci, op. cit., p. 184.

${ }^{8}$ V. Oderský, H. P. Blavatská, p. 14, [s.d, s.1.] (manuscript) - a lecture given in the interwar period, File: Polish Theosophical Society, Documentation Centre of the Congress of Poles in the Czech Republic in Český Těšín (Ośrodek Dokumentacyjny Kongresu Polaków w Republice Czeskiej, Czeski Cieszyn).

${ }^{9}$ I.T. Budil, op. cit., p. 289. 
concerning the internationalisation of the Theosophical movement. In 1897, Hartmann created the International Theosophical Brotherhood in Leipzig (de. Internationale Theosophische Verbrüderung $)^{10}$ whereas Steiner cooperated in that period closely with the parent Theosophical Society of Adyar and was a proclaimer of establishing national sections of this organisation among particular European nations. In 1902-1912 he was a secretary for the German chapter of the Theosophical Society with its seat in Adyar.

\section{The Theosophical movement in Bohemia during Austro-Hungarian rule}

The first theosophical ideas from the above-mentioned German city of Elberfeld spread to the Habsburg Monarchy and found their supporters there as well. A dynamic occult subculture found many supporters, especially in Vienna, where Friedrich Eckstein founded the Theosophical Society in 1887. The first known proclaimer of the theosophical ideas in the Czech lands was a deputy to the Vienna Parliament and the mayor of the town of Jindřichův Hradec, Baron Adolf Franz Leonhardi (18561908), ${ }^{11}$ who belonged to numerous foreign occult associations. Among others, he was a member of the London Theosophical Society and at the same time a member of the Vienna Theosophical Lodge. In the 1880s he met a group of Prague spiritualists and told them about a "completely different manner of studying invisible phenomena, namely about theosophy, occultism, mysticism and other matters." ${ }^{12}$ With support of the members of the Vienna Theosophical Lodge and the involvement of another fascinator of theosophical teachings and the later writer Gustav Meyrink (Gustav Meyer, 1868-1932), he led to the founding of the Theosophical Lodge in Prague in 1891, called "Under the Blue Star" (cs. U modré hvězdy). Among the members were Czechs and Germans, but because Meyrink as a chairman could not speak Czech, the activity was conducted in German. Many members had left the Lodge in the early years of its activity and so the Lodge was inactive in 1895-1897. Only on 28 September 1897 was it was reactivated as the Theosophical Society (cs. Teosofický spolek), led by Alois Koch. ${ }^{13}$ At the moment of its formation it had 29 members. The Prague organisation was not the only theosophical centre in the Czech lands. There were also other groups of theosophists in Ústi nad Labem, Brno, Varnsdorf, Jablonec nad Nisou, Prrerov, Cheb, Teplice, and Střekov. In the first decade of the 20th century, the

${ }^{10}$ T. Zdražil, Theosofie v Praze, „Pagine Historie-Sborník Státního ústředního archivu” 1998, no. 6, p. 22.

${ }_{11}$ T. Zdražil, Počátky theosofie a antroposofie v Čechách. Rudolf Steiner - Praha, Opava a Třebovice, Březnice 1997, p. 15.

${ }^{12} \mathrm{~K}$. Weinfurter, Z mých vzpomínek na založení Theosofické Společnosti v Praze, "Okultní a spiritualistická revue" 1921 , no. 1, p. 9.

${ }^{13}$ National Archives in Prague (cs. Národní archiv Praha), archival collection (hereinafter: a.c.) the Czech Gubernium 1884-1900 (cs. České místodržitelství), Theosophical Society (cs. Teosofický spolek), fasc. V 30/124/12, box 3947. 
first followers of Theosophy appeared also in Teschen Silesia, where this movement was in opposition to spiritualism, which was very developed in this area. ${ }^{14}$

The Theosophical movement started playing a more important role in the Czech lands after the founding of the Theosophical Society, when their own Czech theosophical magazine started being published. The magazine was read by hundreds of readers and some public lectures were given. In 1905 the society had 74 members. After the death of the first chairman Alois Koch in 1904, Jan Bedrníček (1878-1939) became involved in the society, performing various functions, and then in 1908 he became its chairman. ${ }^{15}$ Under his leadership the Theosophical Society was transformed into the Czech Theosophical Society at the turn of August and September of the same year (cs. Česká theosofická společnost), and the following year, it was included into the parent Theosophical Society in Adyar as the Czech section. Evidence of this act was provided by the Polish researchers from Krakow, Izabela Trzcińska and Agata Świerzowska, who studied the case on the spot. ${ }^{16}$

A special role among the Prague theosophists was played by Berta Fanta (18661918). In her house on the old town market square she ran informal, social and intellectual salons called Fantakreis, during which the teachers of the German University in Prague discussed Hegel, Kant and other philosophers and thinkers, as well as German scientists. It was once the most expressive intellectual centre in Prague. Frequent guests of those meetings were Albert Einstein, Philip Frank, Hugo Bergmann and Felix Weltsch. ${ }^{17}$ Other sources say that among the participants of the regular Tuesday meetings were people like mathematician Prof. Kowalewski, Max Brod and Franz Kafka. ${ }^{18}$ Prague was also visited by guests, leading representatives of neighbouring, German speaking countries. One of them, Rudolf Steiner, made the theosophical concepts particularly attractive for many intellectuals of German Prague. Thanks to Berta Fanta, who invited Steiner to her salon, the university elite had the opportunity to learn about theosophical concepts. Steiner also reached the provinces. It is known that he stayed in Ostrava and Třebovice in 1901, ${ }^{19}$ when he was the guest of the Silesian writer Maria Stona (1861-1944), who wrote in German.

Steiner's lectures and his teachings exerted a different influence on leading Prague intellectuals. Einstein had feelings which were completely negative. The greatest interest in theosophy and Steiner's teachings was shown by Franz Kafka. ${ }^{20}$

${ }^{14}$ About the beginnings of spiritualism in Silesia: M. Jemelka, "Sešli jsme se jako křestané": Počátky lidového spiritismu ve Slezsku do jeho institucionalizace v letech 1914-1919, "Slezský sborník" 2016, vol. 114, no. 2, pp. 27-45.

${ }_{15}$ Z. Vojtíšek, Encyklopedie náboženských směrů v České republice. Náboženství, církve, sekty, duchovni společenství. Prague 2004, p. 230.

${ }^{16}$ I. Trzcińska, A. Świerzowska, J. Szymeczek, Z dziejów polskiej teozofii, [in:] Polskie tradycje ezoteryczne 1890-1939, M. Rzeczycka, I. Trzcińska (eds.), vol. 1. Teozofia i antropozofia, Gdańsk 2019, pp. $38-130$.

${ }^{17}$ M. Wein, Slovanský Jeruzalém. Jak Češi založili Izrael, trans. J. Čábela, Praha 2018, p. 36.

18 T. Zdražil, Theosofie v Praze..., op. cit., p. 27.

${ }_{19}$ Idem, Poćátky theosofie..., op. cit., p. 79.

${ }^{20}$ Idem, Theosofie v Praze..., op. cit., p. 30. 
Steiner made a huge impression on Czech theosophists and left a clear mark in the Czech Republic. He contributed to the transformation of the Theosophical Society into the Czech Theosophical Society (cs. Česká theosofická společnost) in 1908, which became the Czech section of the world-wide, parent Theosophical Society in Adyar. He also had an influence on Berta Fanta, who founded the German branch of the Czech Theosophical Association in 1911. It was named after Bernard Bolzano. That step was an augury of serious problems that were to appear in the theosophical movement in the near future. Making the Czech Theosophical Association the Czech section of the parent Theosophical Society in Adyar was one of the last manifestations of cooperation between Steiner and the parent centre in Adyar.

\section{Krishnamurti and the Order of the Star in the East}

After the death of the first chairman of the Theosophical Society with the seat in Adyar, Henry Steel Olcott (1832-1907) ${ }^{21}$ in 1907, Annie Besant (1847-1933) became a new leader of the Theosophical Society. From the very beginning, Steiner and Besant had opposing visions about the future of the Theosophical Society. The differences particularly concerned the purpose of their activities, tasks and ways of attracting a wider audience. Besant planned to transform the Theosophical Society into a new religious trend that would be led by "Jesus Christ incarnated again," whereas Steiner found such beliefs dangerous and pernicious, and looked for another way to apply theosophical teachings to human life. Annie Besant did not have the same fears. She lived in the sphere of intellectual influence of people who thought differently, especially the brilliant but extremely controversial Charles W. Leadbeater (1854-1934). Leadbeater was considered an extraordinary person by his followers. Even in the mid-1920s, when numerous controversies arose around him, he was considered an exceptional spiritual leader. ${ }^{22}$ When Besant, under the influence of Leadbeater, announced the Hindu boy Jid (Jiddu) Krishnamurti (1895-1986) ${ }^{23}$ a new Messiah for the contemporary world, Besant and Steiner parted ways.

In order to prepare members and the entire world to a new Messiah, the Order of the Star in the East was founded in 1911. The purpose of the order was to unite all people who believed in the coming of the Great Spiritual Teacher and wanted to devote their strength to prepare the way for him. ${ }^{24}$ The only condition for membership was faith in the new Messiah. The Order's symbol was a smooth, five-pointed silver

${ }^{21}$ For the purpose of an explanation it should be noted that although Helena P. Blavatsky was the founder of the Theosophical Society, she was not its chairman. In the United States, at the time the Society was founded (1875), women were not allowed to run organisations of such type. For this reason, her close associate Henry Steel Olcott became the first chairman and Blavatsky was entrusted with the function of secretary.

22 "Przegląd Teozoficzny" 1928, vol. 14, no. 2, p. 3.

23 B. French, Leadbeater, s.v. Charles Webster, [in:] Dictionary of Gnosis \& Western Esotericism..., p. 685 .

24 Apart from the Order of the Star in the East, another order was also found, with the similar objects of activity and name: Order of the Rising Sun. 
star. The Order caused tensions in individual theosophical national sections and sometimes led to divisions. Strange and often fanatical manifestations around Krishnamurti caused the withdrawal of the most progressive members from the Theosophical Society. One of them was Steiner, who left the Theosophical Society along with the entire German section in 1913 and founded his own Anthroposophical Society. ${ }^{25}$ The divisions also affected the Prague branch. It was about the group led by Berta Fanta, the German branch of the Czech Theosophical Society, who left the Society in 1912 and later founded the German Anthroposophical Society "Bolzano," with its seat in Prague. At the first stage the conflict affected mainly the German-speaking part of the Czech Theosophical Society, as the Czech-speaking part remained unaffected. The Czech-speaking part of the theosophists associated in the Czech Theosophical Society remained loyal towards the parent Theosophical Society in Adyar. In 1913 some discussions about the divisions written by the Czech Theosophists appeared in Lotus Magazine but they were of rather mild character. The management of the Society, probably in fear of losing a large number of its members, wanted to maintain the most tolerant position towards all parties. Despite that a few people of Czech nationality also left the Society. During the Great War (1914-1918) the conflict in the Czech lands calmed down, to resume with all zeal some years later yet under different social and political conditions. The first conflict concerning the acceptance of Krishnamurti as the new Messiah gave the Czech-speaking theosophists domination in the Czech lands in theosophical circles. Most, but not all, of the German-speaking members shifted towards the anthroposophical movement of Rudolf Steiner.

\section{The Theosophical movement in Czechoslovakia after World War I}

After World War I, thanks to the continuation of the Austrian legal system in the newly created Czechoslovak state, the Czech Theosophical Association could easily resume and continue its activity in a pre-war scope, based on the statute approved on the grounds of a pre-war decision of the imperial-royal ministry of the interior dated 28 August 1908. The Society was the Czech national section of the parental Theosophical Society in Adyar. ${ }^{26}$ Restoration of the Czech Theosophical Society was initiated together with the reconstruction of local groups (lodges) in Prague, where the Society headquarters was located, Varnsdorf and Brno. Some new circles were formed, including in the Moravian Ostrava region. Apart from the Czech theosophical organisation that also associated the German people, in the Czech part of the Teschen Silesia a new, dynamic theosophical organisation was formed: The Polish Theosophical Society in Czechoslovakia in Nydek. ${ }^{27}$ For the whole interwar period,

25 Z. Vojtíšek, Encyklopedie náboženských směrů a hnutí v České republice. Náboženství, církve, sekty, duchovni společenství, Praha 2004, p. 229.

${ }^{26}$ In the report years 1920-1921, the Theosophical Society with its seat in Adyar had 1349 sections (lodges, circles) and 40,475 members in more than 40 countries in the world.

${ }^{27}$ National Archives in Opava (cs. Zemský archiv Opava, hereinafter ZA Opava), a.c: Silesian Regional Government in Opava (cs. Zemská vláda Slezska, hereinafter referred to as: ZVS Opava), The Polish Theosophical Society (pl. Polskie Towarzystwo Teozoficzne), ref. no. XII-16, box 4706. 
the position of the Society's chairman was held by Andrzej Kajfosz (1889-1970). ${ }^{28}$ The theosophical environment in the region of Moravian Ostrava was the most important for the further turn of events, so more attention had to be given to it.

The statute of local circles (lodges) of the Czech Theosophical Society in Moravian Ostrava was approved by the National Political Board in Brno (cs. Zemská správa politická v Brně) on 6 July 1920 on the basis of a request filed by the Prague centre on 11 November 1920. Among the founders of the Ostrava Theosophical Lodge were members of the Prague headquarters, Rudolf Smejkal and Václav Cimr. ${ }^{29}$ Both had business concerns in the region of Ostrava. Smejkal was the owner of the electrotechnical plant located in Mariánské Hory on 155 Palacký's Trail (now part of Ostrava), and Cimr was his partner. The first inaugural lectures were given by renowned lecturers from Prague, among them the president of the Czech headquarters, Jan Bedrníček and writer and translator Pavla Moudrá (1861-1940), who devoted her whole life to work in pacifistic, temperance, and animal welfare movements. The lectures were given at the Belveder Hotel in Mariánské Hory, member meetings at the local school, and later in the boys' school in B. Pecka Street in Moravian Ostrava. ${ }^{30}$ The first lectures concerned the principles of theosophy, but there was also a lecture about Christmas. The lectures were given in small groups, sometimes only for seven people. The Ostrava circle in 1920-1922 numbered about 100 people and the local theosophical library had 150 volumes. After the early boom years, there was another crisis as membership decreased. Apparently, the problem was the distance between Ostrava and Prague. The Circle Board, formed by third persons, was not able to pay sufficient attention to the members. Change only took place when Josef Škuta from Kunčičky (now part of Ostrava), born on 1895 in Michálkovice, a mining clerk at the Alexander mine in Kunčičky, ${ }^{31}$ was elected the chairman during the general meeting of the Ostrava circle on 2 October 1923. The last general meeting of the Ostrava Lodge of the Czech Theosophical Society was held in October 1925. Then there was a crisis among the Czech theosophists, with the main role played by Josef Škuta.

\section{Crisis in the Theosophical circles in Czechoslovakia}

The exact course of the crisis is difficult to describe due to a lack of sources. Some materials of an official character have been preserved in national archives, yet they do not fully reflect the atmosphere of discussions and arguments during the theosophical meetings. One valuable source, Lotus Magazine of the Czech theosophists ceased publication in December 1924.

28 J. Szymeczek, s.v. Andrzej Kajfosz, [in:] Biografický slovník Slezska a severní Moravy, vol. 10, L. Dokoupil (ed.), Ostrava 1998, p. 78-79.

${ }^{29}$ ZA Opava, Police Directorate in the Moravian-Ostrava (cs. Policejní ředitelství Moravská Ostrava, hereinafter referred to as: P̌̌ MO), the Czech Theosophical Society (cs. Česká společnost theosofická), ref. no. 1160/1, box 1091.

${ }^{30}$ Ibidem.

${ }^{31}$ Ibidem. 
Although we do not have many sources and we are not able to learn fully about the conflict, nor listen to particular arguments, the basis of the conflict seems to be clear. Once again, the Czech theosophists were absorbed by a high wave of emotions, which was evoked in individual theosophical sections by the attempt to accept the concept of Krishnamurti as the Saviour and Teacher of the world. In 1925 the Czech Theosophical Society decided to become an independent entity and definitely cut ties with the Theosophical Society in Adyar because it became aware of the senselessness of those "apostolic" actions. ${ }^{32}$ After theosophy became so discredited that the use of that word in public space did not fall within the limits of human decency, the Czech Theosophical Society resigned from its old name in 1927 and took a new one: Society for Mystical Studies (cs. Společnost pro mystická studia). 1927 did not, however, mean the end of the Theosophical movement in Czechoslovakia as sometimes suggested by some popular publications.

Not all Czech theosophists were willing to accept the breakup of the society. Attempts to maintain the Theosophical movement in Czechoslovakia in its original form and to maintain contact with the Society in Adyar were made by the aforementioned Ostrava theosophist Josef Škuta. In order to strengthen his position in the Czech Theosophical movement and to protect the movement in the Czech lands from a real disaster, he tried to cooperate with theosophists from Teschen Silesia associated with the Polish Theosophical Society with its seat in Nydek led by Andrzej Kajfosz. At that time, the organisation had almost 200 members and was the most numerous theosophical group in the entire Czech Republic. Before Kajfosz formed his own society, he had been a member of the Czech Theosophical Association in Prague since 1908, so he had his own opinions on Adyar's teachings. He did not have much trust in Škuta and did not believe in the sincerity of his intentions. The difference in social status (Škuta was a clerk, Kajfosz a miner, then a farmer) and in nationality (Škuta was Czech, Kajfosz a Pole) was another reason for the lack of trust, which became obvious a few years after the bloody Czech-Polish conflict over Teschen Silesia. Kajfosz was wary of all proposals for "closer cooperation." He was an isolated person. As the main argument against amalgamation with the Czech section of the Society in Adyar, he presented the fact that the Polish Theosophical Society with its headquarters in Warsaw also maintained its independence. Yet it had changed and Kajfosz needed to defend his position. Some free groups of the Polish theosophists that appeared in Warsaw at the beginning of the 20th century kept in touch with Adyar from the very beginning, although they did not form an autonomous Polish section within the Theosophical Society. Only in 1923 was the Polish national section entered into the list of national sections of the Theosophical Society with its seat in Adyar. The Order of the Star in the East was also founded in interwar Poland. The Order's Secretary for the region of Małopolska was Henryk Münch in Krakow, at Szczepański Square 2.33

32 T. Zdražil, Theosofie v Praze..., op. cit., p. 33.

33 Documentary Center of the Congress of Poles in Český Těšín (pl. Ośrodek Dokumentacyjny Kongresu Polaków Czeski Cieszyn). Collection: Polish organisations (pl. Organizacje polskie), file: The Polish Theosophical Society (pl. Polskie Towarzystwo Teozoficzne), Leaflet: The Eastern Star Order (pl. Zakon Gwiazdy na Wschodzie). 
Andrzej Kajfosz, as the chairman of the Polish Theosophical Society in Teschen Silesia, did agree with the plans of the Czech Society. A few meetings in Ostrava were dedicated to the matter of connecting the Polish and the Czech theosophical lodges, and the participants tried to reach an agreement but to no avail. Kajfosz was not convinced of the plans and the amalgamation did not happen. Yet not all groups of the Polish theosophists accepted his attitude. It is known that in 1927 two Polish groups from the area of Ostrava and Karvina (original name: Zagłębie OstrawskoKarwińskie), in particular the Jutrzenka group from Karviná ${ }^{34}$ and the Przebudzenie group from Horní Sucha ${ }^{35}$ took part in parties organised by the Czech theosophists, and in the following year they formally joined the Czech Theosophical Society.

The Polish groups entered into a new society formed in 1927 by Josef Škuta on the remains of the previous Czech Theosophical Society. He developed a new statute, registered with the Ministry of Interior on 8 November 1927. The official name of the organisation of the Czech Theosophists was the Theosophical Society in Czechoslovakia (T.S. Adyar) with its seat in Moravian Ostrava. The first general meeting of the new organisation was held on 21 December 1927 at the hotel Imperial in Moravian Ostrava. ${ }^{36}$ According to police data, at that time the Society had 102 members, who declared Czech, Polish and German nationalities. The post of chairman in the following years was held by Josef Škuta (1927-1929), Josef Parchanský, a technical clerk residing in Petřvald near Orlová (1929-1930), Josef Škuta (1930-1936?), and Václav Cimr from Prague (1936-1939?).

In 1928 the organisation had seven lodges (the Czech lodge Adyar in Varnsdorf, the Czech lodge Blavatska in Moravian Ostrava, the Czech lodge Komenský in Michálkovice, the Polish lodge Przebudzenie in Horní Suchá, the Polish lodge Jutrzenka in Karviná, the German lodge St. Alban in Brno, and the Czech lodge Arjuna in Prague). ${ }^{37}$ Apart from these lodges, there were also six centres, subsidiaries of the parent lodges, with a few members. They were located in the following towns and cities: Kopřivnice, Štítina (near Opava), Petřvald, Žarošice (near Kyjov), Štěpánov (near Olomouc) and Brno. On 14 October 1928 the entire Society had 114 members. ${ }^{38}$ The organisation was dissolved in 1939 and was not re-established after World War II. ${ }^{39}$

${ }^{34}$ ZA Opava, a.c: ZVS Opava, Theosophical Society in Czechoslovakia, Karvina's branch (cs. Theosofická společnost v Československu, pobočka Karviná), ref. no.: XII-1718, box 4774.

${ }^{35}$ ZA Opava, a.c.: SVZ Opava, Theosophical Society in Czechoslovakia, Horní Sucha's branch (cs. Theosofická společnost v Československu, pobočka Horní Suchá), ref. no.: XII-1719, box 4774.

${ }^{36}$ ZA Opava, a.c.: PŘ MO, the Theosophical Society in Czechoslovakia (T.S. Adyar) (cs. Theosofická společnost v Československu (T.S. Adyar)), ref. no. 459/5, box 1008.

${ }^{37}$ Documentary Centre of the Congress of Poles in Český Těšín (pl. Ośrodek Dokumentacyjny Kongresu Polaków Czeski Cieszyn), collection: Polish organisations (pl. Organizacje polskie), file: The Polish Theosophical Society (pl. Polskie Towarzystwo Teozoficzne), Minutes from the General Meeting of the Theosophical Society in Czechoslovakia held on 14 October 1928 in Moravian Ostrava (cs. Valná hromada Theosofické společnosti v Československu konaná dne 14. ř́rjna 1928 v M. Ostravě).

${ }^{38}$ Ibidem.

${ }^{39}$ Andrzej Kajfosz made some attempts to reactivate the Theosophical movement in the Czech lands after World War II. The statute of the new society was approved by the authorities on 5 March 1948. The Theosophists Society acted under the official name of the Theosophical Society for Moravian Silesia 


\section{The Order of the Star in Czechoslovakia}

As mentioned above, Josef Škuta was an ardent follower and propagator of the teachings of Krishnamurti, and he spread his messianic mission. He was in close contact with the Order's structures, although it is not known whether he took part in the meetings of the society in Ommen in the Netherlands that were held in 1927 and 1929. ${ }^{40}$ Both were essential. The first one because it was a great inspiration for all the followers awaiting a new master. The name of the society was changed from the Eastern Star Order to the Star Order because it was thought that the revelation of the supreme teacher Krishnamurti had already taken place. With his attitude and fiery speeches, Krishnamurti convinced all participants that "the word was made flesh." Triumphal overtones were heard also in Ostrava. At that time Josef Škuta was trying his best to register the Order in the Czech offices, but it was not easy. The process of legalisation of the Eastern Star Order in Czechoslovakia (cs. Řád hvězdy východní v Československu) began in August 1926 and was successfully completed on $26 \mathrm{Sep}-$ tember 1927. ${ }^{41}$ Then the offices registered the Star Order (cs. Řád Hvězdy) as a legally acting social organisation with its seat in Moravian Ostrava, from where activity was conducted throughout Czechoslovakia. Before the final, positive decision on the approval of the Eastern Star Order was made, the Ministry of the Interior in Prague had had to consider the matter eight times and to issue eight resolutions on the matter. ${ }^{42}$ Because of that, the Order was not released from its obligation to pay a rather high fee for registration, which was done in other cases with understanding. Škuta was reproached for the obscurity of the Order's activities, and for various formal mistakes. The statute stated that the Society's purpose was "to prepare for the coming of the master." It was enquired into what the statute meant by "master." ${ }^{43}$ A number of similar terms were also pointed out. Škuta explained that he considered Jesus Christ as the Master. He did not mention that Krishnamurti was supposed to be his embodiment. Although he tried to be careful, he was suspected of attempting to form a religious association which would require another legal procedure to legitimate. People were also afraid that the Order could become a fanatical sect of a new kind. However, after long explanations the association was successfully formed. They created a library and established a local circle in Michálkovice (now part of Ostrava)

(cs. Teozofická společnost pro Zemi Moravskoslezskou). The Society existed till the end of 1951; then it was dissolved under the pressure of the communist authorities. More information about the post-war history of the Theosophical Society in Czechoslovakia is available in J. Szymeczek, Towarzystwo Teozoficzne, "Biuletyn" no. 2, Documentation Centre of the Congress of Poles in the Czech Republic, Český Těšín 1996, p. 28-35. Also in: Idem: The Religiosity of Czech Society, Ostrava 2013.

${ }^{40}$ Krotona, Theosophy and Krishnamurti 1927-1931. Archival Documents of the Theosophical Society's Esoteric Center, Krotona, in Ojai California, Krotona 2011 (Krotona Series, vol. 5). Also in: M. Lutyens, Krishnamurti. The Years of Awakening, London 1975; P. Jayakar, Krishnamurti. A Biography, San Francisco 1986.

${ }^{41}$ ZA Opava, a.c: PǨ MO, the Easter Star Order (cs. Řád Hvězdy východní), ref. no. 2 176, box 1150.

42 Ibidem.

${ }^{43}$ Ibidem. 
under leadership of the clerk Josef Parchanský from Michálkovice. ${ }^{44}$ And then came the disappointment.

In the city of Ommen in the Netherlands, the next Meeting of the Star Order, no less essential than the previous one, took place on the 3 August 1929. During the Meeting, Krishnamurti unexpectedly dissolved the Order and told all its members to withdraw from its structures. Josef Škuta did not obey Krishnamurti's order and did not dissolve the Order in Czechoslovakia. In 1938 the Order had 120 members. In mid-1938 Andrzej Kajfosz, the president of the Polish Theosophical Society in Slovakia with its seat in Nydek, for the purpose of maintaining fraternal relations with the former members of the Society, visited Polish theosophical circles from the region of Ostrava and Karvina in order to verify the manner of acting of the followers of Theosophy and whether their admiration for Krishnamurti's ideology had ceased. ${ }^{45}$ In the report from that meeting he wrote: "On the grounds of the speech by Alojzy Kaczyński and of the whole course of the Meeting it may be concluded that the local theosophists did not change..." ${ }^{46}$ The Order existed until the end of the Czechoslovak Republic. After the war, Škuta did not return to the Theosophical Society, nor did he resume the activities of the Star Order. He was believed to have become a communist activist. Once he appeared to lecture at a meeting of the Ostrava association "Psyché." The following information was recorded in the chronicle: "The lecture was of unsatisfactory quality. The lecturer confused his views on the divine idea with the advancement of the material spirit. His lecture was constructed in a manner, that if we mix all the colours together, we get grey." ${ }^{\prime 47}$ The life of Josef Škuta confirms that the cultural impact of theosophy can sometimes be very ambivalent. Nicolas Goodrick-Clarke has shown how the theosophical symbols were used in Nazism. ${ }^{48}$ At the end of his life Josef Škuta tried to use the same theosophical symbols in communist ideology.

\section{Summary}

The Theosophical movement came to the Czech lands from Germany. In the beginning Prague was the main area of influence, and the first Theosophical Lodge was created there in 1891. German theosophist Rudolf Steiner played a significant role in the

${ }^{44}$ ZA Opava, a.c.: PŘ MO, the Easter Star Order, Michálkovice circle (cs. Rád Hvězdy východní, pobočka Michálkovice), ref. no. 2 194, box 1150.

${ }^{45}$ Regional Branch of the National Archives in Frýdek-Místek (cs. Státní oblastní archiv FrýdekMístek), a.c.: Theosophical Society in Nýdek (cs. Teosofická společnost Nýdek), report book of the Polish Theosophical Society in Nýdek 1934-1939, Board activity report of 15 June 1938.

${ }^{46}$ Ibidem.

${ }^{47}$ Archives of Ostrava (cs. Archiv města Ostravy), Psyché Association in Prague, circle in Ostrava (cs. Spolek "Psyché" v Praze, odbočka v Ostravě), report book (cs. Kniha protokolů) from 17 December 1946 to 18 April 1951, entry of 9 June 1948.

${ }^{48}$ N. Goodrick-Clarke, Okultní kořeny nacismu. Tajné árijské kulty a jejich vliv na nacistickou ideologii, trans. M. Korbelík, Praha 2005. About activity of the "Psyché" Association in Ostrava: J. Sanitrák, Dějiny české mystiky 2. Konec zlaté éry. Praha 2007, pp. 88-99. 
process of shaping the theosophical teachings in Bohemia. It was mainly on his initiative that the proper organisational structures were created, and his publishing activity with the Czech theosophical "Lotus Magazine" was also important. The Czech Theosophical Society became a national chapter of Theosophical Society headquartered in Adyar, India. This happened at the time when the world's Theosophical movement was hit by a crisis caused by members of society preparing the world for the coming of "born-again Christ." At that time The Order of the Star in the East was created as well. The strange, often fanatical behaviour around the coming of the new Messiah prompted the most progressive of its members to leave the Theosophical Society. In the Czech community two crises occurred. The first was before World War I the Great War, when the Czech Theosophical Society was abandoned by a large group of German-speaking theosophists centred around Berta Fanta who later established the Bolzano Anthroposophical Society. The second was in the aftermath of the disputes around the new Messiah, after World War I, when further divisions appeared. The remaining Czech theosophists gathered around the centre in Moravská Ostrava, where they sometimes supported and sometimes fought against the Polish theosophists, who worked in another Polish Theosophical Society in the Czech part of Teschen Silesia. The Order of the Star of the East was active in Czechoslovakia until 1939.

\section{References}

\section{Primary sources}

National Archives in Prague (cs. Národní archiv Praha)

The Czech Gubernium 1884-1900 (cs. České mistodržitelstvi), file: Theosophical Society (cs. Teosofický spolek).

National Archives in Opava (cs. Zemský archiv Opava)

Police Directorate in the Moravian-Ostrava (cs. Policejni reditelstvi v Moravské Ostravě)

Silesian National Government in Opava (cs. Zemská vláda Slezska Opava)

Regional Branch of the National Archives in Frýdek-Místek (cs. Státní oblastní archiv FrýdekMístek)

Theosophical Society in Nýdek (cs. Teosofická společnost Nýdek).

Archives of Ostrava (Archiv města Ostravy)

Psyche Association in Prague, circle in Ostrava (cs. Spolek "Psyché" v Praze, odbočka v Ostravè)

Documentary Centre of the Congress of Poles in Český Těšín (pl. Ośrodek Dokumentacyjny Kongresu Polaków Czeski Cieszyn)

Polish organisations (pl. Organizacje polskie), File: The Polish Theosophical Society (pl. Polskie Towarzystwo Teozoficzne).

\section{Secondary Sources}

Budil I.T., Spiritualismus a odvrácená strana přirody, Praha 2017.

Carlson M., No Religion Higher than Truth. A History of the Theosophical Movement in Russia 1875-1922, Princeton 1993. 
Goodwin J., Blavatsky and the First Generation of Theosophy, [in:] Handbook of the Theosophical Current, O Hammer, M. Rothstein (ed.), Leiden-Boston 2013.

Goodrick-Clarke, N., Okultní kořeny nacismu. Tajné árijské kulty a jejich vliv na nacistickou ideologii, trans. M. Korbelík, Praha 2005.

Jayakar P., Krishnamurti. A Biography, San Francisco 1986.

Jemelka M., Sešli jsme se jako křest’ané. Počátky lidového spiritismu ve Slezsku do jeho institucionalizace v letech 1914-1919, "Slezský sborník" 2016, no. 2, pp. 27-45.

Krotona, Theosophy and Krishnamurti 1927-1931. Archival Documents of the Theosophical Society's Esoteric Center, Krotona, in Ojai California, Krotona 2011 (Krotona Series, vol. 5).

Lutyens M., Krishnamurti. The Years of Awakening, London 1975.

Oderský V., H. P. Blavatská, [s.d, s.1.] (manuscript).

"Przegląd Teozoficzny" 1928.

Sanitrák J., Dějiny české mystiky 2. Konec zlaté éry, Praha 2007.

Santucci J. A., Helena Petrovna Blavatsky, [in:] Dictionary of Gnosis \& Western Esotericism, W.J. Hanegraaff et al. (eds.), Leiden-Boston 2005, pp. 171-185.

Smoley R., Zakázaná víra. Gnostický odkaz od evangelii po da Vinciho kód, trans. A. Zábojníková, Praha 2009, p. 156.

Szymeczek J., Andrzej Kajfosz, [in:] Biografický slovník Slezska a severni Moravy, vol. 10, L. Dokoupil (ed.), Ostrava 1998, pp. 78-79.

Szymeczek J., The Religiosity of Czech Society, Ostrava 2013.

Szymeczek J., Towarzystwo Teozoficzne, "Bulletin" no. 2, Documentation Centre of the Congress of Poles in the Czech Republic 1996, pp. 28-35.

Trzcińska I., Świerzowska A., Szymeczek J., Z dziejów polskiej teozofii, [in:] Polskie tradycje ezoteryczne 1890-1939, M. Rzeczycka, I. Trzcińska (eds.), vol. 1. Teozofia i antropozofia, Gdańsk 2019, pp. 38-130.

Vojtíšek Z., Encyklopedie náboženských směrů a hnutí v České republice. Náboženství, církve, sekty, duchovni společenství, Praha 2004.

Wein M., Slovanský Jeruzalém. Jak Češi založili Izrael, trans. J. Č́ábela, Praha 2018.

Weinfurter K., Z mých vzpomínek na založení Theosofické Společnosti v Praze, "Okultní a spiritualistická revue" 1921, no. 1, p. 9.

Zdražil T., Theosofie v Praze, "Pagine Historie - Sborník Státního ústředního archivu" in Prague 1998, no. 6, pp. 22-37.

Zdražil T., Počátky theosofie a antroposofie v Čechách. Rudolf Steiner - Praha, Opava and Třebovice, Březnice 1997. 